\title{
Effects of sheep manure in agricultural soils on the behavior of Folsomia candida and initial growth and development of Avena sativa
}

\author{
T. Zortéa ${ }^{a}$ (D), J. C. Segat ${ }^{b}$ (D), R. A. Conte (D), D. A. Barreta $^{b}$ (D), A. W. L. Silva (D), $^{\text {(D) }}$ \\ A. T. Paulino ${ }^{\text {(1) }}$ and D. Baretta ${ }^{b}$ \\ aUniversidade Tecnólogica Federal do Paraná, Pato Branco, PR, Brasil \\ bUniversidade do Estado de Santa Catarina, Departamento de Zootecnia, Chapecó, SC, Brasil \\ c Universidade do Estado de Santa Catarina, Departamento de Engenharia Química e Alimentos, Pinhalzinho, SC, Brasil \\ *e-mail: juliasegat@yahoo.com.br
}

Received: February 26, 2020 - Accepted: April 21, 2020 - Distributed: November 30, 2021

(With 4 figures)

\begin{abstract}
The aim of this study was to evaluate the effects of sheep manure in agricultural soils on the behavior of Folsomia candida and initial growth and development of Avena sativa. For this, an Oxisol was submitted to different doses of sheep manure and was subsequently evaluated for Folsomia candida survival and avoidance behavior through standardized ecotoxicological assays, the initial performance of oats by germination test and the soil basal respiration rate by respirometry methodology. There was an increase in the basal respiration rate of the soil by the application of sheep manure and this was consistent with the increase of the doses. The survival rate and avoidance behavior of springtails were not altered and there was no change in the initial performance of oats, indicating that this manure can be used for organic fertilization of soils with low soil pollutant potential.
\end{abstract}

Keywords: animal manure, ecotoxicology, organic fertilization, soil bioindicator.

\section{Efeitos do esterco de ovelha em solos agrícolas no comportamento de Folsomia candida e no crescimento e desenvolvimento inicial de Avena sativa}

\begin{abstract}
Resumo
O objetivo deste estudo foi avaliar os efeitos do esterco de ovelha em solos agrícolas no comportamento de Folsomia candida e no crescimento e desenvolvimento inicial de Avena sativa. Para isso, um Latossolo foi submetido a diferentes doses de esterco de ovelha e posteriormente avaliado quanto ao comportamento de fuga e a sobrevivência de Folsomia candida por meio de ensaios ecotoxicológicos padronizados, desempenho inicial da aveia pelo teste de germinação e taxa respiratória basal do solo pela metodologia da respirometria. Houve um aumento na taxa de respiração basal do solo pela aplicação de esterco de ovelha e isso foi consistente com o aumento das doses. A taxa de sobrevivência e o comportamento de fuga dos colêmbolos não foram alterados e não houve alteração no desempenho inicial da aveia, indicando que esse esterco pode ser usado para fertilização orgânica de solos com baixo potencial poluente no solo.
\end{abstract}

Palavras-chave: dejeto animal, ecotoxicologia, fertilização orgânica, bioindicador de solo.

\section{Introduction}

The agricultural crops around the world contribute to increase the environmental pollution indices due to usual applications of synthetic agricultural fertilizers in soils (Lopes and Lopes, 2011). Sustainable agricultural practices are important to reduce the environmental impacts caused by the conventional agricultural fertilization (Sambuichi et al., 2012). The organic fertilization of soil with animal manure can be an economically and environmentally viable alternative as it increases the nutrient bioavailability for plants. Moreover, the organic fertilization is a relevant practice for the recovery of degraded and nutrient-poor soils (Severino et al., 2006). Hence, the organic fertilization processes decrease the cost of agricultural practices, in addition to avoid environmental impacts as those caused by application of synthetic agricultural fertilizers (Silva et al., 2010a).

Sheep manure significant amounts containing high agricultural nutrient concentrations are commonly generated by sheep farming (Souza et al., 2012). Such residues are potential agricultural organic fertilizers for the sustainable enrichment of nutrient-poor soils. Sheep manure-based organic fertilizers are employed as substrates for the growth and development of different microorganisms and plants (Souza et al., 2012). However, their applications 
in agricultural soils must be controlled with the aim of avoiding environmental pollution due to the presence of pathogenic species and high concentrations of nitrogen, phosphorus and toxic metals (Alves et al., 2008).

The contamination of agricultural soil is often evaluated by measuring the biological activities according to protocols of the International Organization for Standardization (ISO) (Kuperman et al., 2009; Nyemeier et al., 2009). These protocols were developed to perform soil ecotoxicological assays using plants, microorganisms and bioindicators such as springtails, earthworms and enchytraeids (Edwards, 2004). These bioindicators are sensitive to changes in the soil quality due to environmental pollution, which is not detected when using synthetic indicators (Araújo and Monteiro, 2007; Filser et al., 2014). The aim of this study was to evaluate the effects of sheep manure in agricultural soils on the survival and avoidance behavior of Folsomia candida, on the initial growth and development of Avena sativa and the microbial activities in Oxisol.

\section{Materials and Methods}

\subsection{Soil samples}

Soil samples were collected at depths of 0 to $20 \mathrm{~cm}$ from an Oxisol located in the West of the State of Santa Catarina, Brazil. The soil samples were dried in a greenhouse at $55.0 \pm 1.0^{\circ} \mathrm{C}$, milled and sieved to $2.0 \mathrm{~mm}$. Soil samples for microbial assays were dried at room temperature and stored at $3.0 \pm 0.1{ }^{\circ} \mathrm{C}$. Next, the $\mathrm{pH}$ value was adjusted to $6.0 \pm 0.5$ by adding $\mathrm{CaCO}_{3}$ (ISO, 2005a) and water content was adjusted to $65 \%$ to water holding capacity (ISO, 1998). The physicochemical properties of the soil were obtained by protocol described by Raij et al. (2001) and are shown in Table 1.

\subsection{Sheep manure samples}

Sheep manure samples were collected from a slatted floor located in the West of the State of Santa Catarina, Brazil. These samples were sieved to $4.0 \mathrm{~mm}$ using granulometric sieves, transferred to plastic bags and stored in refrigerator at $3.0 \pm 0.1^{\circ} \mathrm{C}$ prior to chemical analyzes and applications as organic fertilizers. The physiochemical properties of the sheep manure samples were obtained using the protocol described by Tedesco et al. (1995) and are shown in Table 2 .

\subsection{Experimental design}

All tests conducted were assembled under a completely randomized design with five replications. The treatments consisted of the combination of Oxisol with the different doses of sheep manure applied to the soil. For plant tests, manure was applied to the surface, according to the normal conditions of use of this material in agricultural areas. For the tests with organisms and microbial activity, the manure was incorporated into the soil, through manual agitation until the mixture was homogenized. The doses used were the equivalent to $0,2,4,8$ and $16 \mathrm{Mg} \mathrm{ha}^{-1}$.

\subsection{Microbial activities in soil}

Sheep manure increasing doses were appropriately mixed and homogenized with soil samples. Subsequently, $50 \mathrm{~g}$ of sheep manure/soil mixture were placed in hermetic glass flasks. Next, $25 \mathrm{~mL}$ of $0.050 \mathrm{~mol} \mathrm{~L}^{-1}$ sodium hydroxide solution was added in each flask, which were left for 10 days at temperature of $28 \pm 1{ }^{\circ} \mathrm{C}$ in absence of light. The sodium hydroxide solution was daily renewed during a 10 days incubation period. The carbonate formed in the alkaline aqueous solution was precipitated with $5 \mathrm{~mL}$ of $0.050 \mathrm{~mol} \mathrm{~L}^{-1}$ barium chloride solution as described by Alef and Nannipieri (1995). The carbon content released in the soil was determined by titration of the sodium hydroxide solution with $0.050 \mathrm{~mol} \mathrm{~L}^{-1}$ standard hydrochloric acid solution, using phenolphthalein as acid-base indicator.

\subsection{Folsomia candida survival}

The survival of Folsomia candida were determined according to the procedure ISO 11267 (ISO, 1999) as follows: $30 \mathrm{~g}$ of the mixture, soil with sheep manure doses, were placed in glass flasks. Next, ten Folsomia candida synchronized organisms (10 to 12 days old) were also placed in each flask. Afterwards, the springtails were fed with biological yeast and monitored for 14 days. The flasks were placed in an air-conditioned room with at $20+2{ }^{\circ} \mathrm{C}$ and photoperiod of 12:12 h (light:dark). After 14 days, the contents of the flasks were transferred to another container, added $150 \mathrm{~mL}$ of water and 5 drops of black pen ink and carefuly stirred for 30 seconds. Surviving springtails floated on the water surface allowing the counting of individuals.

Table 1. Physiochemical properties of the Oxisol collected at depths of 0 to $20 \mathrm{~cm}$.

\begin{tabular}{|c|c|c|c|c|c|c|c|c|c|c|c|}
\hline \multirow{2}{*}{$\mathrm{CEC}^{1}$} & $\mathbf{O M}^{2}$ & Clay & $\mathbf{P}$ & $K$ & $\mathbf{C a}$ & Mg & Al & $\mathbf{H}+\mathbf{A l}$ & $\mathbf{C u}$ & Zn & $\mathrm{Fe}$ \\
\hline & \multicolumn{2}{|c|}{$\%$} & \multicolumn{2}{|c|}{$\mathrm{mg} \mathrm{kg}^{-1}$} & \multicolumn{4}{|c|}{ cmolc kg $^{-1}$} & \multicolumn{3}{|c|}{$\mathrm{mg} \mathrm{kg}^{-1}$} \\
\hline 12.34 & 3.9 & 55.0 & 3.5 & 124.0 & 3.2 & 1.0 & 48.2 & 7.83 & 1.4 & 0.8 & 79.7 \\
\hline
\end{tabular}

${ }^{1} \mathrm{CEC}$ - Cation-exchange capacity at $\mathrm{pH} 7.0 ;{ }^{2} \mathrm{OM}$ - Organic Matter

Table 2. Physiochemical properties of the sheep manure samples.

\begin{tabular}{|c|c|c|c|c|c|c|c|c|c|}
\hline DOM $^{1}$ & $\mathbf{P}$ & $\mathbf{K}$ & $\mathbf{N}$ & $\mathrm{Ca}$ & Mg & $\mathbf{N a}$ & $\mathrm{Cu}$ & Zn & Mn \\
\hline$\%$ & \multicolumn{3}{|c|}{$\mathrm{mg} \mathrm{kg}^{-1}$} & \multicolumn{3}{|c|}{${\text { cmolc } \text { kg }^{-1}}^{1}$} & \multicolumn{3}{|c|}{$\mathrm{mg} \mathrm{kg}^{-1}$} \\
\hline 57.25 & 7.48 & 26.0 & 2.72 & 0.85 & 0.72 & 650.0 & 24.35 & 10.6 & 598.0 \\
\hline
\end{tabular}




\subsection{Folsomia candida avoidance behavior}

The avoidance behavior of Folsomia candida were performed according to the procedure ISO 17512-1 and 2 (ISO, 2005b; 2007) as follows: $30 \mathrm{~g}$ of control soil (soil without sheep manure) and $30 \mathrm{~g}$ of the mixture, soil with sheep manure doses, were separately placed, side by side, in a cylindrical plastic flask (diameter: $6.5 \mathrm{~cm}$, height: $5.5 \mathrm{~cm}$ ) divided by a plastic plate. After the removal of the plate, 20 juveniles of springtails (Folsomia candida) with ages from 10 to 12 days were placed in the center of the cylindrical plastic flask and left for $48 \mathrm{~h}$. Then, the control soil and soil with sheep doses were transferred separately to two other containers and $150 \mathrm{~mL}$ of water and 5 drops of black pen ink were added, this solution was stirred for 30 seconds. Surviving springtails floated on the water surface allowing the counting of individuals.

\subsection{Initial growth and development of Avena sativa}

The assays for the initial growth and development of Avena sativa were performed according to adaptation of OECD 208 (OECD, 2008) procedure as follow: $250 \mathrm{~g}$ of soil were placed in plastic vessels containing one gravel layer at the bottom and one sand layer upon the gravel layer. Next, 22 seeds of Avena sativa were planted in each vessel, applying increasing doses of sheep manure on top of the soil $\left(0,2,4,8\right.$ and $\left.16 \mathrm{Mg} \mathrm{ha}^{-1}\right)$. The initial growth and development of Avena sativa were monitored for 14 days. The germination rates of the seeds and heights of the plants were determined after 7 and 14 days of experiment.

\subsection{Statistical analysis}

Data were tested for homogeneity of variance and normality and subsequently subjected to analysis of variance (ANOVA) for the basal respirometry assays using LSD tests $(\mathrm{P}<0.05)$ (Statsoft, 2004). The Folsomia candida survival assays and seed germination rate was performed using analysis of variance (one-way) with Dunnett's tests $(\mathrm{P}<0.05)$ (Statsoft Statistica 7.0 2004). The avoidance percentage (A, \%) of Folsomia candida was calculated using Equation 1:

$$
\mathrm{A}, \%=\frac{\mathrm{C}-\mathrm{T}}{\mathrm{N}} \times 100
$$

in which $\mathrm{C}$ is the springtail amount in the control soil, $\mathrm{T}$ is the springtail amount in the sheep manure/soil mixture and $\mathrm{N}$ is the total springtail amount determined by the Fisher test $(\mathrm{P} \leq 0.05)$ (Zar, 2014).

\section{Results}

\subsection{Microbial activities in soil}

Figure 1 displays the carbon concentrations in the control soil $(\mathrm{C} 0)$ and soils containing sheep manure increasing doses as a function of the incubation days. The carbon concentrations increased with the increase of the incubation days and sheep manure doses, at a $95 \%$ significance level $(\mathrm{P}<0.05)$. The carbon concentrations in the soils containing from 2.0 to $16 \mathrm{Mg}$ sheep manure per ha soil ranged from 27.59 to $72.84 \mathrm{mg}$ carbon per $\mathrm{g}$ soil, respectively, whereas the carbon concentration in the control soil was $18.31 \mathrm{mg}$ carbon per g soil.

\subsection{Folsomia candida}

Figure 2 displays the survival mean rates of Folsomia candida in the control ( $\mathrm{C} 0$ ) and sheep manure-enriched soils as a function of the sheep manure increasing doses. Figure 3 displays the avoidance percentages of Folsomia candida from the control soil $(\mathrm{C} 0)$ to sheep manure-enriched soils as a function of the sheep manure increasing doses. The sheep manure increasing doses from 0 to $16 \mathrm{Mg}$ sheep manure per ha soil were not toxics for the Folsomia candida at a 95\% significance level $(\mathrm{P}<0.05)$.

\subsection{Initial growth and development of Avena sativa}

Figures 4a-c display the germination rates (a), heights after 7 days (b) and heights after 14 days (c) of Avena sativa grown in the control soils (C0) and soils containing 2, 4, 8 and $16 \mathrm{Mg}$ sheep manure per ha soil. Avena sativa is a plant that has been widely employed for ecotoxicological assays with the aim of determining the environmental pollution indices of different soils. Significant harmful effects were not observed during the initial growth and development of Avena sativa in the study soils. The germination rates, heights after 7 days and heights after 14 days of incubation were similar at a 95\% significance level $(\mathrm{P}<0.05)$.

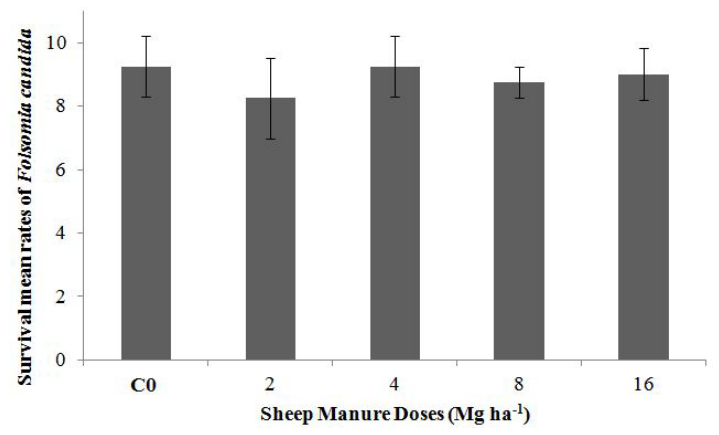

Figure 1. Survival mean of Folsomia candida in the control (C0) and sheep manure-enriched soils as a function of the sheep manure increasing doses.

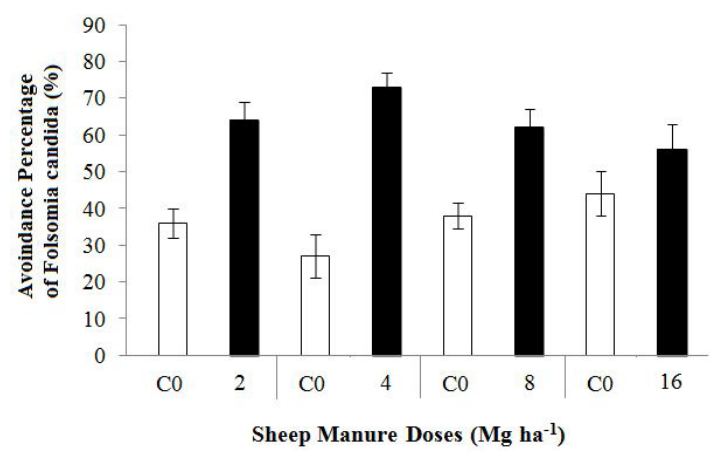

Figure 2. Avoidance percentages of Folsomia candida from the control soil (C0) for sheep manure-enriched soils as a function of sheep manure increasing doses. 


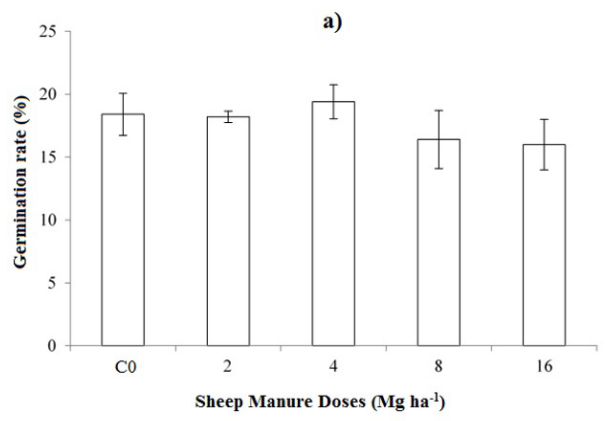

b)

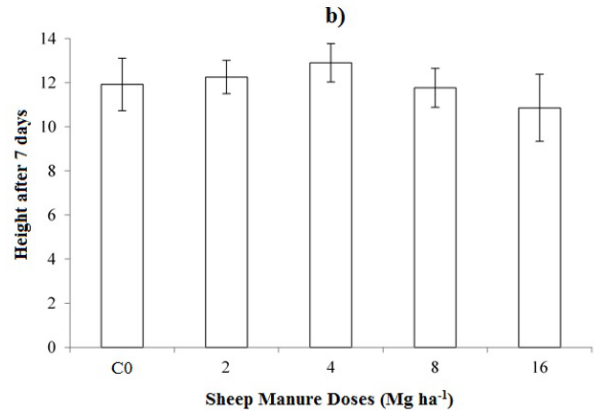

c)

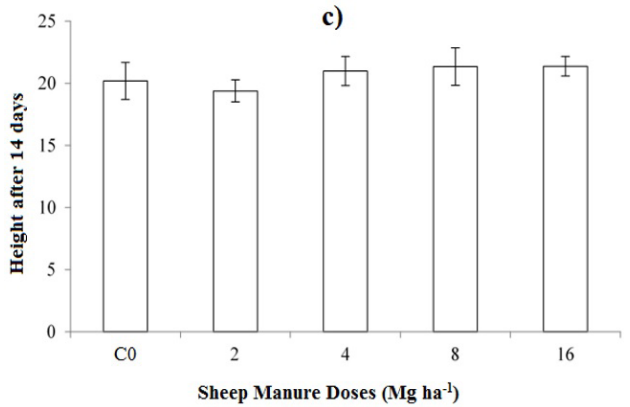

Figure 3. Germination rates (a), heights after 7 days (b) and heights after 14 days (c) of Avena sativa grown in the control soils (C0) and soils containing 2, 4, 8 and $16 \mathrm{Mg}$ sheep manure per ha soil.

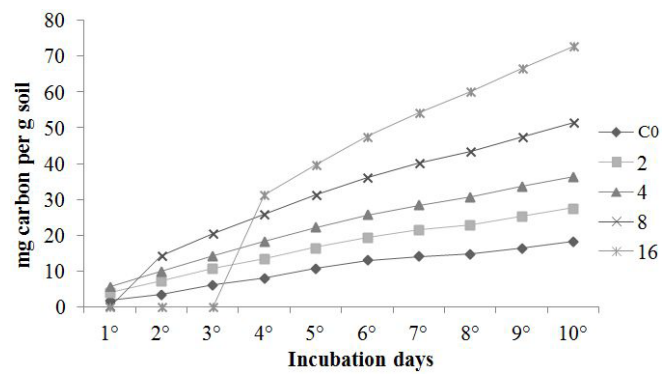

Figure 4. Carbon concentrations in the control soil (C0) and soils containing sheep manure increasing doses as a function of the incubation days.

\section{Discussion}

The microbial respiratory activities were higher in the sheep manure-enriched soils than control soil, indicating higher organic matter decomposition rates as already described by Moura et al. (2015). The microbial respiration rates in soils depend on the microorganism physiological and cell properties, which change with humidity, temperature, nutrient bioavailability, texture, carbon/nitrogen ratio and manure dose (Silva et al., 2010b). The microbial activities were inhibited with sheep manure doses of $16 \mathrm{Mg}$ sheep manure per ha soil from the first to third incubation day. The microbial activities due to carbon release increase the fermentation processes (Silva et al., 2010b), increasing the organic matter contents, bioavailable mineral concentrations (Severino et al., 2006) and nutrient cycles (Sharma et al., 2013). Moreover, the carbon release increases the nitrogen mineralization (Franzluebbers et al., 2000), improving the plant growth indices due to higher nutrient bioavailability. Higher microbial activities in animal manure-enriched soils can also indicate an increase in the environmental pollution due to anthropological activities (Martines et al., 2006). Finally, the application of animal manure increasing doses in soils has to be controlled during the organic fertilization processes with the aim of avoiding the environmental pollution and increasing the plant growth indices.

The springtail survival rate in soil is employed as an environmental pollution bioindicator as this organism is sensitive to different pollutants in ecotoxicological assays (Araújo and Monteiro, 2007). In general, it is possible to infer that sheep manure is not as harmful for soils and plants as swine manure (Zórtea et al., 2018). This can be related with the high zinc and copper concentrations in swine manure, which are toxics for springtails and plants (Wolf et al., 2017). Otherwise, low metal concentrations and high carbon/nitrogen ratios in sheep manure increase the microbial activities in agricultural soils (Antoniolli et al., 2013), enabling the use of this manure as organic biofertilizer.

The avoidance percentages of Folsomia candida from the control soil (C0) to soils containing 2, 4, 8 and $16 \mathrm{Mg}$ sheep manure per ha soil were high due to the absence of toxicity and high carbon/nitrogen ratios in the sheep manure. This result was confirmed by observing the highest black bars in the study graphic. Most of springtails preferably remained in the soils containing doses from 0 to $8 \mathrm{Mg}$ sheep manure per ha soil. Lower amounts of Folsomia candida were determined in the soil containing $16 \mathrm{Mg}$ sheep manure per ha soil, indicating that sheep manure doses higher than $16 \mathrm{Mg}$ per ha could be harmful for soils and plants as observed in swine manure-enriched soil (Andrés and Domene, 2005; Wolf et al., 2017) and bovine manure-enriched soil (Matos-Moreira et al., 2011).

Absence of effects until the fourteenth day does not mean that it can be no different for the long-term growth of this plant due to the large amounts of organic matter and nutrients in animal manure enriched soils. The seed reserve composition and mobilization during the plant germination are main factors for the initial growth and development (Mayer and Poljakoff-Mayber, 1975). In this case, the initial growth and development of Avena sativa were not significantly affected by sheep manure doses from 0 to $16 \mathrm{Mg}$ sheep manure per ha soil, probably due to low copper, iron and manganese concentrations (Ganesh et al., 2008). Further studies will be performed 
with the aim of evaluating the long-term harmful effects during the growth of Avena sativa in the control and sheepmanure-enriched soils with the aim of establishing the possible environmental impacts on soils, plants, animals and mesofauna during the organic fertilizations of different crops. The results presented in the work show that the use of sheep manure can cause changes in the dynamics of the environment and that these changes need to be known and understood so that the use is less impatiently negatively possible. In practical terms, it can be understood that the use of organic fertilizers is a practice widely used in Brazil, but with little knowledge of the effects it causes on the ecosystem.

\section{Acknowledgments}

The authors gratefully acknowledge the CNPq and FAPESC for research support.

\section{References}

ALEF, K. and NANNIPIERI, P., 1995. Methods in applied soil microbiology and biochemistry. London: Academic Press. 576 p.

ALVES, M.V., SANTOS, J.C.P., GOIS, D.T., ALBERTON, J.V. and BARETTA, D., 2008. Soil macrofauna as influenced by chemical fertilizers and swine manure use in western Santa Catarina State, Brazil. Revista Brasileira de Ciência do Solo, vol. 32, no. 3, pp. 589-598. http://dx.doi.org/10.1590/S0100-06832008000200014.

ANDRÉS, P. and DOMENE, X., 2005. Ecotoxicological and fertilizing effects of dewatered, composted and dry sewage sludge on soil mesofauna: a TME experiment. Ecotoxicology (London, England), vol. 14, no. 5, pp. 545-557. http://dx.doi.org/10.1007/ s10646-005-0006-8. PMid:16220361.

ANTONIOLLI, Z.I., REDIM, M., SOUZA, E.L. and POCOJESKI, E., 2013. Heavy metal, pesticides and fuels: effect in the population of collembola in the soil. Ciência Rural, vol. 43, no. 6, pp. $992-$ 998. http://dx.doi.org/10.1590/S0103-84782013005000056.

ARAÚJO, A.S.F. and MONTEIRO, R.T.R., 2007. Biological indicators of soil quality. Bioscience Journal, vol. 23, no. 3, pp. 66-75.

EDWARDS, C.A., 2004 The Importance of Earthworms as Key Representatives of the Soil Fauna. In: C.A. EDWARD, ed. Earthworm Ecology. 2nd ed. Boca Raton: Press pp. 3-11. http:// dx.doi.org/10.1201/9781420039719.pt1.

FILSER, J., WIEGMANN, S. and SCHRÖDER, B., 2014. Collembola in ecotoxicology - Any news or just boring routine? Applied Soil Ecology, vol. 83, pp. 193-199. http://dx.doi. org/10.1016/j.apsoil.2013.07.007.

FRANZLUEBBERS, A.J., HANEY, R.L., HONEYCUTT, C.W., SCHOMBERG, H.H. and HONS, F.M., 2000. Flush of carbon dioxide following rewetting of dried soil relates to active organic pools. Soil Science Society of America Journal, vol. 64, no. 2, pp. 613-623. http://dx.doi.org/10.2136/sssaj2000.642613x.

GANESH, K.S., BASKARAN, L., RAJASEKARAN, S., SUMATHI, K., CHIDAMBARAM, A.L.A. and SUNDARAMOORTHY, P., 2008. Chromium stress induced alterations in biochemical and enzyme metabolism in aquatic and terrestrial plants. Colloids and Surfaces. B, Biointerfaces, vol. 63, no. 2, pp. 159-163. http:// dx.doi.org/10.1016/j.colsurfb.2007.11.016. PMid:18206355.

INTERNATIONAL ORGANIZATION FOR STANDARDIZATION - ISO, 2005a. ISO 10390: Soil Quality - Determination of pH. Switzerland: CH Geneve.

INTERNATIONAL ORGANIZATION FOR STANDARDIZATION - ISO, 1999. ISO 11267: Soil Quality - Inhibition of reproduction of Collembola (Folsomia candida) by soil pollutants. Switzerland: $\mathrm{CH}$ Geneve.

INTERNATIONAL ORGANIZATION FOR STANDARDIZATION - ISO, 1998. ISO 11274: Soil Quality - Determination of the water-retention characteristic-laboratory methods. Switzerland: CH Geneve.

INTERNATIONAL ORGANIZATION FOR STANDARDIZATION - ISO, 2005b. ISO 17512-1: Soil Quality - Avoidance test for determining the quality of soils and effects of chemicals on behavior - Part 1: test with earthworms (Eisenia fetida and Eisenia andrei). Switzerland: CH Geneve.

INTERNATIONAL ORGANIZATION FOR STANDARDIZATION - ISO, 2007. ISO 17512-2: Soil Quality - Avoidance test for testing the quality of soils and effects of chemicals on behavior-Part 2: Test with collembolan (Folsomia candida). Switzerland: CH Geneve.

KUPERMAN, R.G., CHECKAI, R.T., GARCIA, M.V.B., RÖMBKE, J., STEPHENSON, G.L. and SOUSA, J.P., 2009. State of the science and the way forward for the ecotoxicological assessment of contaminated land. Pesquisa Agropecuária Brasileira, vol. 44, no. 8, pp. 811-824. http://dx.doi.org/10.1590/ S0100-204X2009000800004

LOPES, P.R. and LOPES, K.C.S.A., 2011. Sistemas de produção de base ecológica - a busca por um desenvolvimento rural sustentável. Revista Espaço de Diálogo e Desconexão, vol. 4, no. 1, pp. 1-32. http://dx.doi.org/10.32760/1984-1736/REDD/2011.v4i1.5047.

MARTINES, A.M., ANDRADE, C.A. and CARDOSO, E.J.B.N., 2006. Mineralization of the organic carbon in soils treated with tannery sludges. Pesquisa Agropecuária Brasileira, vol. 41, no. 7, pp. 1149-1155. http://dx.doi.org/10.1590/S0100-204X2006000700011.

MATOS-MOREIRA, M., NIEMEYER, J.C., SOUSA, J.P., CUNHA, M. and CARRAL, E., 2011. Behavioral avoidance tests to evaluate effects of cattle slurry and dairy sludge application to soil. Revista Brasileira de Ciência do Solo, vol. 35, no. 4, pp. 1471-1477. http://dx.doi.org/10.1590/S0100-06832011000400041.

MAYER, A.M. and POLJAKOFF-MAYBER, A., 1975. The germination of seeds. 2nd ed. Oxford: Pergamon Press Ltda. 192 p.

MOURA, J.A., GONZAGA, M.I.S., ANJOS, J.L., RODRIGUES, A.C.P., LEÃO, T.D.S. and SANTOS, L.C.O., 2015. Basal respiration and stratification ratio in soil cultivated with citrus and treated with organic residues in the state of Sergipe. Semina: Ciências Agrárias, vol. 36, no. 2, pp. 732-745. http://dx.doi. org/10.5433/1679-0359.2015v36n2p731.

NYEMEIER, J.C., SANTOS, V.C., ARAÚJO, P.B. and SILVA, E., 2009. Reproduction of Cubaris murina (Crustacea: Isopoda) under laboratory conditions and its use in ecotoxicity tests. Brazilian Journal of Biology $=$ Revista Brasileira de Biologia, vol. 69, no. 1, pp. 137-142. http://dx.doi.org/10.1590/S151969842009000100017. PMid:19347156.

ORGANIZATION FOR ECONOMIC COOPERATION AND DEVELOPMENT - OECD, 2008. OECD 208: Terrestrial plant test: Seedling emergence and seedling growth test. Paris: OEDC. 
RAIJ, B.V., ANDRADE, L.C., CANTARELLA, H. and QUAGGIO, J.A., 2001. Análise química para avaliação da fertilidade de solos tropicais. Campinas: Instituto Agronômico. 285 p.

SAMBUICHI, R.H.R., OLIVEIRA, M.A.C., SILVA, A.P.M. and LEUDEMANN, G., 2012. A sustentabilidade ambiental da agropecuária brasileira: impactos, políticas públicas e desafios. Rio de Janeiro: Institute for Applied Economic Research. 52 p.

SEVERINO, L.S., FERREIRA, G.B., MORAES, C.R.A., GONDIM, T.M.S., CARDOSO, G.D., VIRIATO, J.R. and BELTRÃO, N.E.M., 2006. Castor bean yield and growth responses to organic and mineral fertilizer. Pesquisa Agropecuária Brasileira, vol. 41, no. 5, pp. 879-882. http://dx.doi.org/10.1590/S0100-204X2006000500023.

SHARMA, S.B., SAYYED, R.Z., TRIVEDI, M.H. and GOBI, T.A., 2013. Phosphate solubilizing microbes: sustainable approach for managing phosphorus deficiency in agricultural soils. SpringerPlus, vol. 2, no. 587, pp. 1-14. http://dx.doi.org/10.1186/2193-18012-587. PMid:25674415.

SILVA, F.A.M., VILAS-BOAS, R.L. and SILVA, R.B., 2010a. Response of lettuce to nitrogen fertilization with different organic composts in two successive cycles. Acta Scientiarum. Agronomy, vol. 32, no. 1, pp. 131-137. http://dx.doi.org/10.4025/actasciagron. v32i1.134010.4025/actasciagron.v32i1.1340.

SILVA, R.R., SILVA, M.L.N., CARDOSO, E.L., MOREIRA, F.M.S., CURI, N. and ALOVISI, A.M.T., 2010b. Soil biomass and microbial activity under different management systems in the physiographic region campos das vertentes - Minas Gerais.
Revista Brasileira de Ciência do Solo, vol. 34, no. 5, pp. 15851592. http://dx.doi.org/10.1590/S0100-06832010000500011.

SOUZA, H.A., OLIVEIRA, E.L., MODESTO, V.C., MONTES, R.M. and NATALE, W., 2012. Atributos químicos do solo tratado com composto orgânico de carcaça e despojo de abate de caprinos e ovinos. Technical Report. Sobral: Brazilian Agricultural Research Corporation. $8 \mathrm{p}$.

Statsoft, 2004. [accessed 26 February 2006]. STATISTICA 7.0: Data Analysis Software System. Available from www.statsoft.com

TEDESCO, M.J., GIANELLO, C., BISSANI, C.A. and VOLKWEISS, S.J., 1995. Análises de solo, plantas e outros materiais. 2nd ed. Porto Alegre: UFRGS, Departamento de Solos, 174 p.

WOLF, M., BARETTA, D., BECEGATO, V.A., ALMEIDA, V.C. and PAULINO, A.T., 2017. Copper/zinc bioaccumulation and the effect of phytotoxicity on the growth of lettuce (Lactuca sativa L.) in non-contaminated, metal-contaminated and swine manure-enriched soils. Water, Air, and Soil Pollution, vol. 228, no. 4, pp. 1-9. http://dx.doi.org/10.1007/s11270-017-3345-1.

ZAR, J., 2014. Biostatistical analysis. 5rd ed. New York: Pearson.

ZORTÉA, T., SILVA, A.S., REIS, T.R., SEGAT, J.C., PAULINO, A.T., SOUZA, J.P. and BARETTA, D., 2018. Ecotoxicological effects of fipronil, neem cake and neem extract in edaphic organisms from tropical soil. Ecotocological and Environmental Safety, vol. 166, pp. 207-214. http://dx.doi.org/10.1016/j.ecoenv.2018.09.061. PMid:30269016. 